\title{
Distributions and sources of low-molecular-weight monocarboxylic acids in gas and particles from a deciduous broadleaf forest in northern Japan
}

\author{
Tomoki Mochizuki ${ }^{1, \mathrm{a}}$, Kimitaka Kawamura ${ }^{1,2}$, Yuzo Miyazaki ${ }^{1}$, Bhagawati Kunwar ${ }^{2}$, and \\ Suresh Kumar Reddy Boreddy ${ }^{1}$ \\ ${ }^{1}$ Institute of Low Temperature Science, Hokkaido University, Sapporo, Japan \\ ${ }^{2}$ Chubu Institute for Advanced Studies, Chubu University, Kasugai, Japan \\ anow at: School of Food and Nutritional Science, University of Shizuoka, Shizuoka, Japan
}

Correspondence: Kimitaka Kawamura (kkawamura@isc.chubu.ac.jp)

Received: 3 May 2018 - Discussion started: 14 May 2018

Revised: 4 February 2019 - Accepted: 7 February 2019 - Published: 25 February 2019

\begin{abstract}
To better understand the distributions and sources of low-molecular-weight (LMW) monocarboxylic acids (monoacids) in the forest atmosphere, we conducted simultaneous collection of gaseous and particulate samples at a deciduous broadleaf forest site in northern Japan. LMW normal $\left(\mathrm{C}_{1}-\mathrm{C}_{10}\right)$, branched $\left(\mathrm{iC}_{4}-\mathrm{iC}_{6}\right)$, hydroxyl (glycolic and lactic) and aromatic (benzoic) monoacids were detected in the gas and particle phases. The dominant LMW monoacids in gas phase were formic (mean: $953 \mathrm{ng} \mathrm{m}^{-3}$ ) and acetic $\left(528 \mathrm{ng} \mathrm{m}^{-3}\right)$ acids followed by propionic $\left(37 \mathrm{ng} \mathrm{m}^{-3}\right)$ or isopentanoic $\left(42 \mathrm{ng} \mathrm{m}^{-3}\right)$ acid. In the particle phase, isopentanoic $\left(159 \mathrm{ng} \mathrm{m}^{-3}\right)$ was dominant, followed by acetic $\left(104 \mathrm{ng} \mathrm{m}^{-3}\right)$ and formic $\left(71 \mathrm{ng} \mathrm{m}^{-3}\right)$ or lactic $\left(65 \mathrm{ng} \mathrm{m}^{-3}\right)$ acids. Concentrations of LMW monoacids did not show correlations with anthropogenic tracers such as $\mathrm{nss}^{-} \mathrm{SO}_{4}^{2-}$ and $\mathrm{NO}_{3}^{-}$, indicating that anthropogenic contribution is not important. Concentrations of $\mathrm{C}_{1}-\mathrm{C}_{6}$ monoacids in the gas phase showed positive correlations $\left(r^{2}=0.21-0.91\right)$ with isobutyric acid $\left(\mathrm{iC}_{4}\right)$, which may be produced by microbial activity in soil. The forest soil may be a source of gaseous $\mathrm{C}_{1}-$ $\mathrm{C}_{6}$ monoacids in the forest atmosphere. Acetic acid in the particle phase positively correlated with nonanoic acid $\left(\mathrm{C}_{9}\right)$ $\left(r^{2}=0.63\right)$, suggesting that formation of acetic and nonanoic acids is associated with the oxidation of biogenic unsaturated fatty acids in the aerosol phase, in addition to photochemical oxidation of biogenic volatile organic compounds. The particle-phase fractions $\left(F_{\mathrm{p}}\right)$ of formic and acetic acids showed negative correlation with ambient temperature $\left(\mathrm{C}_{1}\right.$ : $\left.r^{2}=0.49, \mathrm{C}_{2}: r^{2}=0.60\right)$ but showed positive correlation
\end{abstract}

with relative humidity $\left(\mathrm{C}_{1}: r^{2}=0.30, \mathrm{C}_{2}: r^{2}=0.55\right)$ in daytime, suggesting that these meteorological parameters are important for the gas and particle portioning of monoacids in the forest atmosphere.

\section{Introduction}

Homologous series $\left(\mathrm{C}_{1}-\mathrm{C}_{10}\right)$ of low-molecularweight (LMW) monocarboxylic acids (monoacids) are known to exist in the atmosphere as gas and particle phases (e.g., Kawamura et al., 1985, 2000; Liu et al., 2012). They have been reported from urban (Kawamura et al., 2000), forest (Andreae et al., 1988), marine (Miyazaki et al., 2014; Boreddy et al., 2017) and Antarctic samples (Legrand et al., 2004). Formic $\left(C_{1}\right)$ and acetic $\left(C_{2}\right)$ acids are the dominant volatile organic species in the atmosphere. LMW monoacids and their salts in aerosols are water soluble and thus can act as cloud condensation nuclei $(\mathrm{CCN})$, contributing to the Earth radiative forcing directly or indirectly (Kanakidou et al., 2005) and affecting the radiation budget of the atmosphere. Conversely, high abundances of LMW monoacids in the troposphere can potentially have adverse effects on air quality and human health and also increase the acidity of rainwater (Keene et al., 1983; Kawamura et al., 1996).

LMW monoacids are directly emitted from fossil fuel combustion, biomass and biofuel burning (Kawamura et al., 1985; Paulot et al., 2011), and terrestrial vegetation 
(Kesselmeier et al., 1997; Jardine et al., 2011). In addition, secondary production from photochemical oxidations of biogenic volatile organic compounds (VOCs) such as isoprene and anthropogenic VOCs such as acetylene and ethane is an important source of LMW monoacids (Paulot et al., 2011). Recently, Stavrakou et al. (2012) conducted satellite measurements of formic acid on a global scale. They suggest that boreal and tropical forests are important sources of formic acid in the troposphere. In the model experiment, Paulot et al. (2011) estimated that the global sources of formic and acetic acids are $\sim 1200$ and $\sim 1400 \mathrm{Gmol} \mathrm{yr}^{-1}$, respectively; however, these values are highly uncertain.

In our previous study, normal $\left(\mathrm{C}_{1}-\mathrm{C}_{10}\right)$, branched $\left(\mathrm{iC}_{4}-\right.$ $\mathrm{iC}_{6}$ ) and hydroxy (glycolic and lactic) monoacids were detected in gas, aerosol and snow pit samples (Kawamura et al., 2000; Mochizuki et al., 2016, 2017). In particular, branched $\left(\mathrm{iC}_{5}\right)$ and hydroxy (lactic) monoacids were abundantly detected in aerosol samples from northeast China (Mochizuki et al., 2017). Detected branched $\left(\mathrm{iC}_{4}\right.$ and $\left.\mathrm{iC}_{5}\right)$ and hydroxy (lactic) monoacids are likely derived from microorganisms and plants (Curl, 1982; Effmert et al., 2012). However, those monoacids have not been reported in the forest atmosphere, in which an ion chromatograph was used, and the species detected are generally limited to formic and acetic acids (Tsai and Kuo, 2013). Because LMW monoacids including hydroxy acids are highly water soluble, they can alter the hygroscopic properties of atmospheric particles. There is no study on gas-particle partitioning of normal $\left(\mathrm{C}_{1}-\mathrm{C}_{10}\right)$, branched $\left(\mathrm{iC}_{4}-\mathrm{iC}_{6}\right)$ and hydroxy (glycolic and lactic) monoacids in the forest atmosphere. Therefore, the study of LMW monoacids in forest is important.

In this study, we collected gas and particle samples from a deciduous broadleaf forest of northern Japan in summer. To better understand the distributions and sources of LMW monoacids, the samples were analyzed for normal $\left(\mathrm{C}_{1}-\mathrm{C}_{10}\right)$, branched $\left(\mathrm{iC}_{4}-\mathrm{iC}_{6}\right)$, hydroxyl (glycolic and lactic) and aromatic (benzoic) monoacids in both gas and particle phases using capillary gas chromatography. Inorganic ions were measured in the particle phase. We discuss the importance of monoacid-enriched aerosols and their possible sources in the forest atmosphere.

\section{Experiment}

The Sapporo forest meteorology research site (SAP) $\left(42^{\circ} 59^{\prime} \mathrm{N}, 141^{\circ} 23^{\prime} \mathrm{E}, 182 \mathrm{~m}\right.$ a.s.l. $)$ is located in a hilly area (147 ha) neighboring the urban district of Sapporo, Hokkaido, Japan (Fig. 1). Residential areas are located north, east and west of the site. The forest type is matured secondary deciduous broadleaf forest. The major tree is Japanese white birch (Betula platyphylla var. japonica) and Japanese oak (Quercus mongolica var. grosse serrata). The major understory is a dwarf bamboo (Sasa kurilensis and Sasa senanensis). Metrological data such as ambient temperature, relative humidity (RH), UV-A, wind speed, wind direction and precipitation were taken at a meteorological tower (Fig. 2). Details of the micrometeorological measurements and site information have been described in Yamanoi et al. (2015) and Miyazaki et al. (2012a, b). During the campaign period (June to July 2010), ambient air temperature ranged from 18 to $26^{\circ} \mathrm{C}$ (average: $21 \pm 2.3^{\circ} \mathrm{C}$ ), whereas $\mathrm{RH}$ ranged from $69 \%$ to $96 \%$ (average: $87 \pm 7.9 \%$ ). UV-A was high during the first half of the campaign (except for 7 July) and low during the second half. The dominant wind direction throughout the campaign was from the east and south. Wind speed ranged from 0.2 to $0.6 \mathrm{~m} \mathrm{~s}^{-1}$ (average: $0.4 \mathrm{~m} \mathrm{~s}^{-1}$ ). Precipitation occurred in the morning of 1 July $(11 \mathrm{~mm})$, in the evening of 4 July $(1.2 \mathrm{~mm})$, and in the morning of 8 July $(6.6 \mathrm{~mm})$.

Samplings were conducted from 28 June to 8 July 2010. The samples were collected for 15 h (05:00-20:00 LT) in daytime $(n=11)$ and $9 \mathrm{~h}(20: 00-05: 00 \mathrm{LT})$ in nighttime $(n=11)$. Total suspended particles (TSPs) and gaseous organic acids were collected using a low-volume air sampler equipped with two-stage filter packs (URG-2000-30FG) at a flow rate of $15 \mathrm{~L} \mathrm{~min}^{-1}$ (Kawamura et al., 1985). The particles were collected onto precombusted $\left(450^{\circ} \mathrm{C}, 6 \mathrm{~h}\right)$ quartzfiber filters (47 mm diameter) (first stage), whereas gaseous organic acids were collected on the quartz-fiber filter impregnated with potassium hydroxide ( $\mathrm{KOH})$ (second stage). The $\mathrm{KOH}$-impregnated filters were prepared by rinsing the precombusted quartz filter in a $0.2 \mathrm{M} \mathrm{KOH}$ solution and then dried in an oven at $80^{\circ} \mathrm{C}$. Each filter was placed in a clean glass bottle with a Teflon-lined screw cap. After the sampling, the filter samples were stored in a freezer room at $-20^{\circ} \mathrm{C}$ prior to analysis. Semi-volatile organic acids collected on the first filter may in part evaporate, causing negative artifacts. Conversely, the second filter may adsorb organic vapors evaporated from the first filter, causing positive artifacts. Although such artifacts are possible for any filterbased measurements under ambient conditions, these effects are minimal (Kawamura et al., 1985).

LMW monoacids were determined as $p$-bromophenacyl esters using a capillary gas chromatograph equipped with a flame ionization detector (GC-FID) and a GC with a mass spectrometer (GC-MS) (Kawamura and Kaplan, 1984; Mochizuki et al., 2017). Briefly, an aliquot of filter $\left(4.3 \mathrm{~cm}^{2}\right)$ was extracted for water-soluble organic compounds with organic-free ultrapure water (resistivity of $>18.2 \mathrm{M} \Omega \mathrm{cm}$ ) under ultrasonication. To remove the particles, water extracts were filtered through a Pasteur pipette packed with quartz wool. The $\mathrm{pH}$ of filtrates was adjusted to 8.5-9.0 with $0.05 \mathrm{M} \mathrm{KOH}$ solution. The samples were concentrated down to $0.5 \mathrm{~mL}$ using a rotary evaporator under a vacuum at $50^{\circ} \mathrm{C}$. The concentrates were passed through a Pasteur pipette packed with a cation exchange resin (DOWEX 50WX4, 100-200 mesh, $\mathrm{K}^{+}$form). Free monocarboxylic acids were converted to organic acid salts $\left(\mathrm{RCOO}^{-} \mathrm{K}^{+}\right)$. After confirming the $\mathrm{pH}$ of 8.5-9.0, the samples were dried using a rotary evaporator under vacuum at $50{ }^{\circ} \mathrm{C}$, followed 

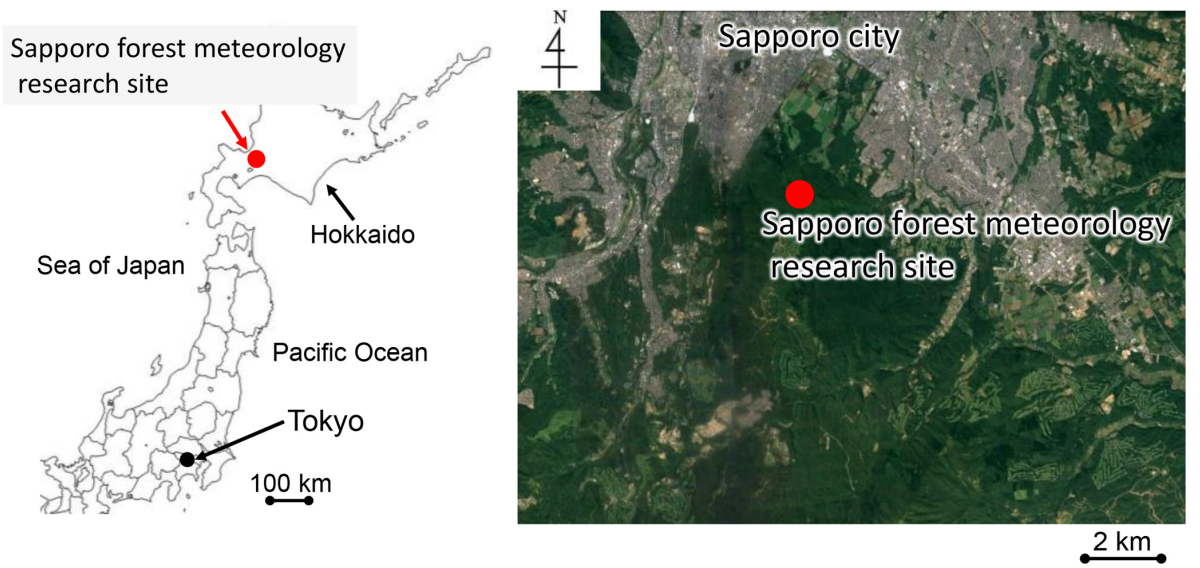

Figure 1. Location of a forest site for air sampling.

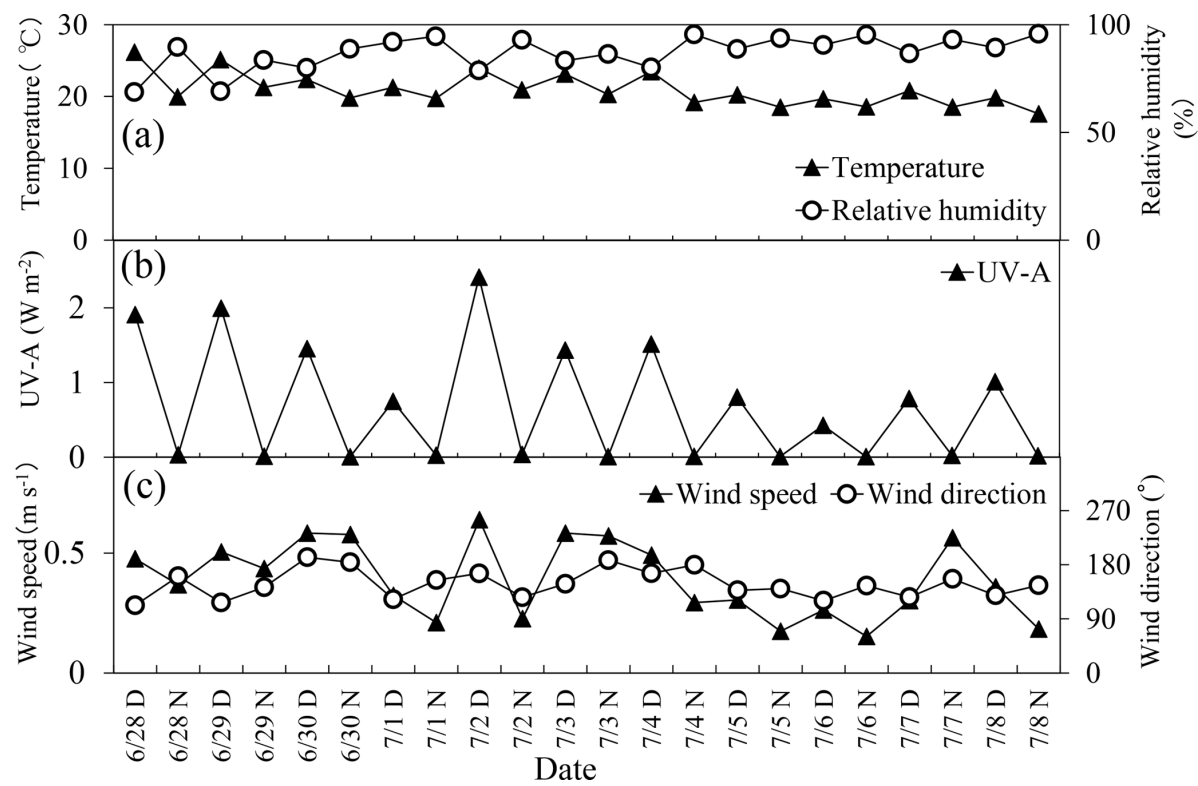

Figure 2. Diurnal and temporal variations in (a) temperature and relative humidity, (b) UV-A, and (c) wind speed and wind direction in a deciduous broadleaf forest.

by blowdown with pure nitrogen gas. Organic acids were derivatized to $p$-bromophenacyl esters in acetonitrile $(4 \mathrm{~mL})$ with $\alpha, p$-dibromoacetophenone $(0.1 \mathrm{M}, 50 \mu \mathrm{L})$ as a derivatization reagent and dicyclohexyl-18-crown-6 $(0.01 \mathrm{M}, 50 \mu \mathrm{L})$ as a catalyst at $80^{\circ} \mathrm{C}$ for $2 \mathrm{~h}$ (Kawamura and Kaplan, 1984). In addition, $\mathrm{OH}$ functional groups in $p$-bromophenacyl esters of hydroxy monoacids were reacted with $\mathrm{N}, \mathrm{O}-$ bis-(trimethylsilyl)trifluoroacetamide (BSTFA) with $1 \%$ trimethylsilyl chloride and $10 \mu \mathrm{L}$ of pyridine at $70^{\circ} \mathrm{C}$ for $3 \mathrm{~h}$ to derive trimethylsilyl (TMS) ethers of $p$-bromophenacyl esters (Kawamura et al., 2012).

$p$-Bromophenacyl esters and their TMS ethers were identified and quantified using a capillary gas chromatograph (HP GC 6890, Hewlett-Packard, USA) equipped with a flame ionization detector and GC-MS (Agilent 7890A and 5975C
MSD, Agilent, USA). Details of the methods have been described in Kawamura and Kaplan (1984) and Kawamura et al. (2012). Recoveries of authentic monoacids $\left(\mathrm{C}_{1}-\mathrm{C}_{10}, \mathrm{iC}_{4-}\right.$ $\mathrm{iC}_{6}$, glycolic, lactic and benzoic acids) spiked to a quartz filter were better than $80 \%$. Analytical errors using authentic monoacids were within $12 \%$.

To measure inorganic ions, a portion of quartz-fiber filter (first stage) was extracted with ultrapure water under ultrasonication. The extracts were passed through a membrane disk filter $(0.22 \mu \mathrm{m}$, Millipore Millex-GV, Merck, USA). The filtrates were injected into an ion chromatograph (model 761 compact IC, Metrohm, Switzerland) (Boreddy and Kawamura, 2015). We measured cations $\left(\mathrm{Na}^{+}, \mathrm{NH}_{4}^{+}, \mathrm{K}^{+}, \mathrm{Mg}^{2+}\right.$ and $\left.\mathrm{Ca}^{2+}\right)$ and anions $\left(\mathrm{F}^{-}, \mathrm{MSA}^{-}, \mathrm{Cl}^{-}, \mathrm{NO}_{2}^{-}, \mathrm{NO}_{3}^{-}, \mathrm{PO}_{4}^{-}\right.$ and $\mathrm{SO}_{4}^{2-}$ ) in aerosol samples. Concentrations of non-sea- 


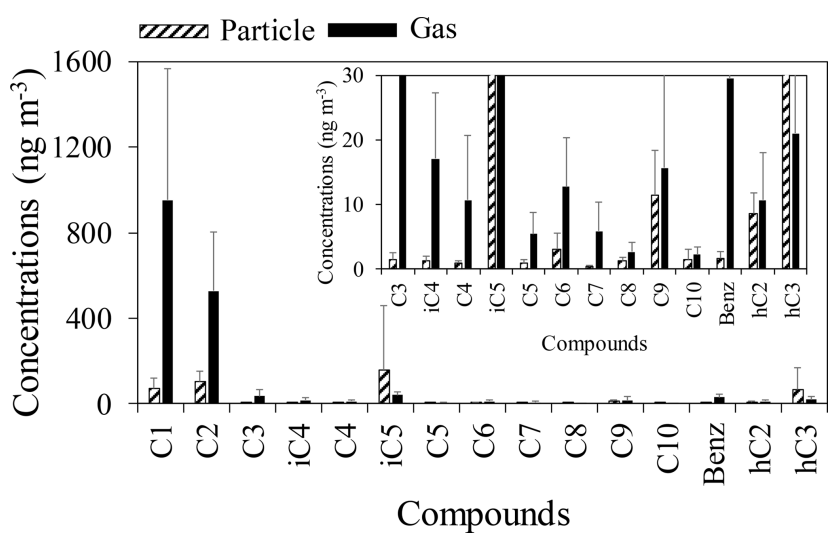

Figure 3. Average concentrations of LMW monocarboxylic acids in the gas and particle phases.

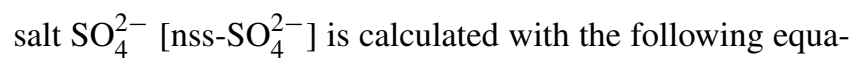
tion:

$\left[n s s-\mathrm{SO}_{4}^{2-}\right]=\left[\mathrm{SO}_{4}^{2-}\right]-0.25 \times\left[\mathrm{Na}^{+}\right]$,

where $\left[\mathrm{SO}_{4}^{2-}\right]$ and $\left[\mathrm{Na}^{+}\right]$are concentrations of total $\mathrm{SO}_{4}^{2-}$ and $\mathrm{Na}^{+}$, respectively (Berg Jr. and Winchester, 1978; Duce et al., 1983).

We calculated 7-day air mass back trajectories at a height of $300 \mathrm{~m}$ a.s.l. using the Meteorological Data Explorer (METEX) provided by the National Institute for Environmental Studies (http://db.cger.nies.go.jp/metex/index.html, last access: 12 August 2018).

\section{Results}

LMW normal $\left(\mathrm{C}_{1}-\mathrm{C}_{10}\right)$, branched $\left(\mathrm{iC}_{4}-\mathrm{iC}_{6}\right)$, hydroxyl (glycolic and lactic) and aromatic (benzoic) monoacids were detected in gas and aerosol samples from a deciduous broadleaf forest in northern Japan (Table 1). Figure 3 shows mean concentrations of monoacids in the gas and particle phases. In the gas phase, formic acid was the dominant species (188-2260 $\mathrm{ng} \mathrm{m}^{-3}$, mean: $953 \mathrm{ng} \mathrm{m}^{-3}$ ), followed by acetic acid $\left(277-1590 \mathrm{ng} \mathrm{m}^{-3}\right.$, mean: $528 \mathrm{ng} \mathrm{m}^{-3}$ ). In the particulate phase, isopentanoic acid was found as the dominant species (36-1478 $\mathrm{n} \mathrm{m}^{-3}$, mean: $159 \mathrm{ng} \mathrm{m}^{-3}$ ), followed by acetic acid (22-263 $\mathrm{ng} \mathrm{m}^{-3}$, mean: $104 \mathrm{ng} \mathrm{m}^{-3}$ ) and formic acid (2.2-216 $\mathrm{ng} \mathrm{m}^{-3}$, mean: $71 \mathrm{ng} \mathrm{m}^{-3}$ ). Lactic acid, which is a hydroxyl monoacid, was generally the fourth most abundant monoacid in particle samples $\left(8.4-522 \mathrm{ng} \mathrm{m}^{-3}\right.$, mean: $65 \mathrm{ng} \mathrm{m}^{-3}$ ).

Figure 4 shows day-night variations in selected monoacids in the gas and particle phases. Gaseous formic acid did not show any day-night trend, whereas particulate formic acid showed a diurnal distribution with higher concentrations in the nighttime than daytime. Abundances of gaseous acetic acid were higher in the daytime than in the nighttime, whereas an opposite trend was found for acetic acid in the particle phase; that is, particulate acetic acid was more abundant in the nighttime than in the daytime, being similar to particulate formic acid. Day-to-day variations in other monoacids did not show a clear diurnal trend.

The highest concentrations of isopentanoic and lactic acids in the particle phase were observed at night on 30 August. Temporal variation in isopentanoic acid in particle phase was similar to that of lactic acid. Gas and particulate concentrations of isopentanoic and lactic acids did not show any clear diurnal variation.

The particle-phase fractions $\left(F_{\mathrm{p}}\right)$ of individual monoacids were calculated as $F_{\mathrm{p}}=P /(G+P)$, where $P$ is particlephase concentration and $G$ is gas-phase concentration. Table 1 summarizes mean $F_{\mathrm{p}}$ of individual monoacids in the daytime and nighttime in the deciduous broadleaf forest. $F_{\mathrm{p}}$ of individual monoacids ranged from $0.04\left(\mathrm{C}_{3}\right)$ to $0.63\left(\mathrm{iC}_{5}\right)$ in the daytime and $0.05\left(\mathrm{C}_{3}\right)$ to $0.69\left(\mathrm{iC}_{5}\right)$ in the nighttime. Formic $\left(\mathrm{C}_{1}\right)$ and acetic $\left(\mathrm{C}_{2}\right)$ acids are largely present in the gas phase. Nonanoic $\left(\mathrm{C}_{9}\right)$ and decanoic $\left(\mathrm{C}_{10}\right)$ acids are present not only in the gas phase but also in the particle phase. Glycolic and lactic acids are largely present in the aerosol phase in the forest atmosphere (Table 1).

We detected cations $\left(\mathrm{Na}^{+}, \mathrm{NH}_{4}^{+}, \mathrm{K}^{+}, \mathrm{Mg}^{2+}\right.$ and $\left.\mathrm{Ca}^{2+}\right)$ and anions $\left(\mathrm{NO}_{3}^{-}, \mathrm{SO}_{4}^{2-}, \mathrm{MSA}^{-}, \mathrm{Cl}^{-}, \mathrm{NO}_{2}^{-}\right.$and $\left.\mathrm{F}^{-}\right)$in particle samples from a deciduous broadleaf forest. $\mathrm{Nss}_{-} \mathrm{SO}_{4}^{2-}$ (mean: $2240 \mathrm{ng} \mathrm{m}^{-3}$ ) is a major anion and $\mathrm{NH}_{4}^{+}$(mean: $972 \mathrm{ng} \mathrm{m}^{-3}$ ) is a major cation. Concentrations of major inorganic ions did not show clear diurnal or temporal variations. The $\mathrm{pH}$ of the water extracts from particle samples ranged from 3.5 to 6.3 (mean: 5.0). We found that particle samples were always acidic in this study.

This forest site is located a few kilometers south of the Sapporo metropolitan area. As discussed in the next section, lifetimes of monoacids are relatively long (e.g., 12.9 days for formic acid), suggesting long-range atmospheric transport of monoacids from other areas. The dominant wind direction was from the east and south throughout the sampling period. We compared the concentrations of individual monoacids together with nss- $\mathrm{SO}_{4}^{2-}$ and $\mathrm{NO}_{3}^{-}$: anthropogenic tracers to evaluate the influence of anthropogenic air mass transport from urban areas. We confirmed that individual monoacids in both the gas and particle phases did not show any significant correlations with nss- $\mathrm{SO}_{4}^{2-}\left(r^{2}<0.14\right)$ and $\mathrm{NO}_{3}^{-}\left(r^{2}<0.11\right)$. The majority of sampled air was not influenced by urban air masses. In addition, Fig. 5 shows 7-day air mass back trajectories ( $300 \mathrm{~m}$ a.s.l.) for the study period from 28 June to 8 July at the sampling site. Most of the air masses passed through the Pacific Ocean during the measurement period, except for 28 June. This result may suggest that the air masses arriving at the forest site are not affected by the outflows from East Asia and Far East Russia. 
Table 1. Average concentrations $\left(\mathrm{ng} \mathrm{m}^{-3}\right.$ ) with standard deviation (SD) of LMW monocarboxylic acids in the gas and particle phases and particle-phase fraction $\left(F_{\mathrm{p}}\right)$ in a deciduous broadleaf forest from northern Japan.

\begin{tabular}{|c|c|c|c|c|c|c|c|c|c|c|c|c|}
\hline \multirow[b]{3}{*}{ Organic acids } & \multicolumn{4}{|c|}{ Particle phase } & \multicolumn{4}{|c|}{ Gas phase } & \multicolumn{4}{|c|}{$F_{\mathrm{p}}$} \\
\hline & \multicolumn{2}{|c|}{ Day } & \multicolumn{2}{|c|}{ Night } & \multicolumn{2}{|c|}{ Day } & \multicolumn{2}{|c|}{ Night } & \multicolumn{2}{|c|}{ Day } & \multicolumn{2}{|c|}{ Night } \\
\hline & Ave. & SD & Ave. & $\mathrm{SD}$ & Ave. & SD & Ave. & SD & Ave. & SD & Ave. & SD \\
\hline \multicolumn{13}{|l|}{ Aliphatic acids } \\
\hline Formic, $\mathrm{C}_{1}$ & 41 & 32 & 99 & 52 & 832 & 627 & 1075 & 572 & 0.08 & 0.07 & 0.11 & 0.11 \\
\hline Acetic, $\mathrm{C}_{2}$ & 81 & 34 & 124 & 54 & 603 & 334 & 431 & 154 & 0.14 & 0.07 & 0.24 & 0.11 \\
\hline Propionic, $\mathrm{C}_{3}$ & 1.5 & 1.1 & 1.5 & 1.3 & 46 & 33 & 27 & 14 & 0.04 & 0.03 & 0.05 & 0.02 \\
\hline Isobutyric, $\mathrm{iC}_{4}$ & 1.1 & 0.8 & 1.3 & 0.7 & 18 & 11 & 16 & 8.4 & 0.07 & 0.05 & 0.08 & 0.04 \\
\hline Butyric, $\mathrm{C}_{4}$ & 0.8 & 0.4 & 0.9 & 0.4 & 13 & 12 & 7.5 & 5.1 & 0.07 & 0.04 & 0.13 & 0.09 \\
\hline Isopentanoic, $\mathrm{iC}_{5}$ & 86 & 72 & 226 & 419 & 41 & 20 & 49 & 17 & 0.63 & 0.19 & 0.69 & 0.14 \\
\hline Pentanoic, $\mathrm{C}_{5}$ & 0.7 & 0.3 & 1.2 & 0.3 & 5.6 & 3.7 & 5.0 & 3.0 & 0.14 & 0.11 & 0.23 & 0.10 \\
\hline Hexanoic, $\mathrm{C}_{6}$ & 1.6 & 1.0 & 4.6 & 2.7 & 12 & 6.3 & 13 & 8.8 & 0.13 & 0.08 & 0.28 & 0.10 \\
\hline Heptanoic, $\mathrm{C}_{7}$ & 0.2 & 0.2 & 0.3 & 0.2 & 4.5 & 3.0 & 7.0 & 5.4 & 0.11 & 0.06 & 0.13 & 0.13 \\
\hline Octanoic, $\mathrm{C}_{8}$ & 0.8 & 0.4 & 1.5 & 0.6 & 2.2 & 1.2 & 3.1 & 1.4 & 0.30 & 0.12 & 0.34 & 0.11 \\
\hline Nonanoic, $\mathrm{C}_{9}$ & 9.2 & 5.5 & 13 & 8.1 & 14 & 24 & 16 & 18 & 0.50 & 0.22 & 0.47 & 0.17 \\
\hline Decanoic, $\mathrm{C}_{10}$ & 1.6 & 1.2 & 1.3 & 1.9 & 1.7 & 0.9 & 2.6 & 1.2 & 0.49 & 0.21 & 0.34 & 0.23 \\
\hline Subtotal & 225 & & 475 & & 1594 & & 1652 & & & & & \\
\hline \multicolumn{13}{|l|}{ Hydroxy acids } \\
\hline Glycolic, Glyco & 8.4 & 3.4 & 8.6 & 3.1 & 11 & 9.4 & 10 & 4.1 & 0.48 & 0.14 & 0.47 & 0.13 \\
\hline Lactic, Lac & 38 & 33 & 90 & 145 & 24 & 21 & 23 & 12 & 0.60 & 0.17 & 0.68 & 0.16 \\
\hline Subtotal & 46 & & 99 & & 36 & & 33 & & & & & \\
\hline \multicolumn{13}{|l|}{ Aromatic acid } \\
\hline Benzoic, Benz & 1.0 & 0.8 & 2.0 & 1.4 & 26 & 18 & 32 & 15 & 0.06 & 0.06 & 0.06 & 0.04 \\
\hline
\end{tabular}

\section{Discussion}

\subsection{Possible sources of LMW monoacids}

To better understand molecular distributions of monoacids in the gas phase (i.e., predominance of formic acid followed by acetic acid), we calculated the lifetimes of gaseous $\mathrm{C}_{1}-$ $\mathrm{C}_{4}$ and $\mathrm{iC}_{4}$ monoacids with $\mathrm{OH}$ radicals $(\mathrm{OH}$ radical concentration $=2.0 \times 10^{6}$ molecule $\mathrm{cm}^{-3}$ ) using the rate constants of gaseous $\mathrm{C}_{1}-\mathrm{C}_{4}$ and $\mathrm{iC}_{4}$ monoacids (provided by NIST Chemical Kinetics Database). The lifetimes of gaseous formic, acetic, propionic, butyric and isobutyric acids with $\mathrm{OH}$ radicals are 12.9, 8.6, 4.8, 3.2 and 2.8 days. These results showed that organic acids are relatively stable with longer lifetimes for shorter-chain monoacids. This unique feature of lifetime can explain the predominance of formic acid due to the accumulation in the gas phase and high concentrations of formic and acetic acids in the atmosphere.

LMW monoacids are directly emitted from fossil fuel combustion (Kawamura et al., 1985) and plant leaves (Kesselmeier and Staudt, 1999) and also produced in the atmosphere by photooxidation of anthropogenic and biogenic VOCs (Paulot et al., 2011). LMW monoacids have a variety of anthropogenic and biogenic sources. In the gas phase, isobutyric acid $\left(\mathrm{iC}_{4}\right)$ showed positive correlations with $\mathrm{C}_{1}$ (day: $r^{2}=0.36$, night: no correlation), $\mathrm{C}_{2}(0.53,0.43), \mathrm{C}_{3}$ $(0.76,0.64), \mathrm{C}_{4}(0.82,0.80), \mathrm{C}_{5}(0.91,0.81)$ and $\mathrm{C}_{6}(0.72$, 0.74) monoacids (Fig. 6). Branched chain monoacids including isobutylic acid are known as common metabolites of bacteria (e.g., Bacteroides distasonis) and fungi in soils (Effmert et al., 2012, and references therein). Correlations of $\mathrm{C}_{1}-\mathrm{C}_{6}$ monoacids with $\mathrm{iC}_{4}$ suggest that forest floor is a source of gaseous $\mathrm{C}_{1}-\mathrm{C}_{6}$ monoacids in the forest atmosphere. $\mathrm{LMW}$ monoacids such as acetic and propionic acids can be produced by microbiological processes (Effmert et al., 2012). In addition, exudation of organic acids is known to occur in vascular plants, mainly from roots (Curl, 1982). Shen et al. (1996) reported that formic, acetic and propionic acids are contained in forest soil and rhizosphere soil.

Although we did not collect a forest soil sample from Sapporo during the air-sampling period, we collected a surrogate soil sample (surface $\sim 3 \mathrm{~cm}$ ) from a broadleaf forest at Chubu University campus in central Japan on 31 October 2018. The forest floor at the Chubu University site is similar to that of the Sapporo site in terms of the coverage with a broadleaf litter from similar plant species including a Japanese oak. The climate in central Japan is different from northern Japan, but the air temperature recorded 


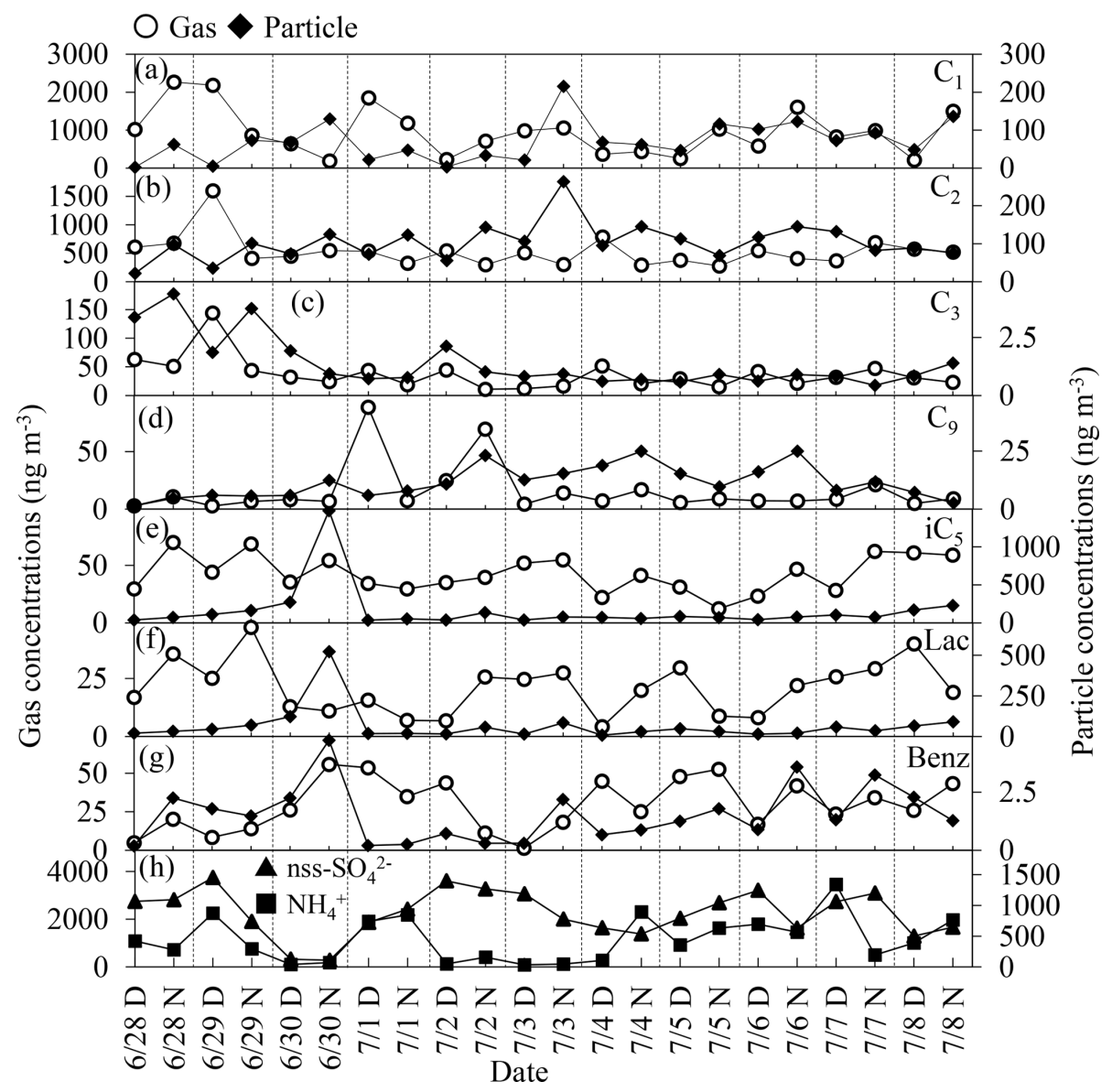

Figure 4. Diurnal variations in the concentrations of major monocarboxylic acids in the gas (open circle) and particle (solid diamond) phases and inorganic ions (nss- $\mathrm{SO}_{4}^{2-}$ and $\mathrm{NH}_{4}^{+}$). Day: $\mathrm{D}$; night: $\mathrm{N}$.

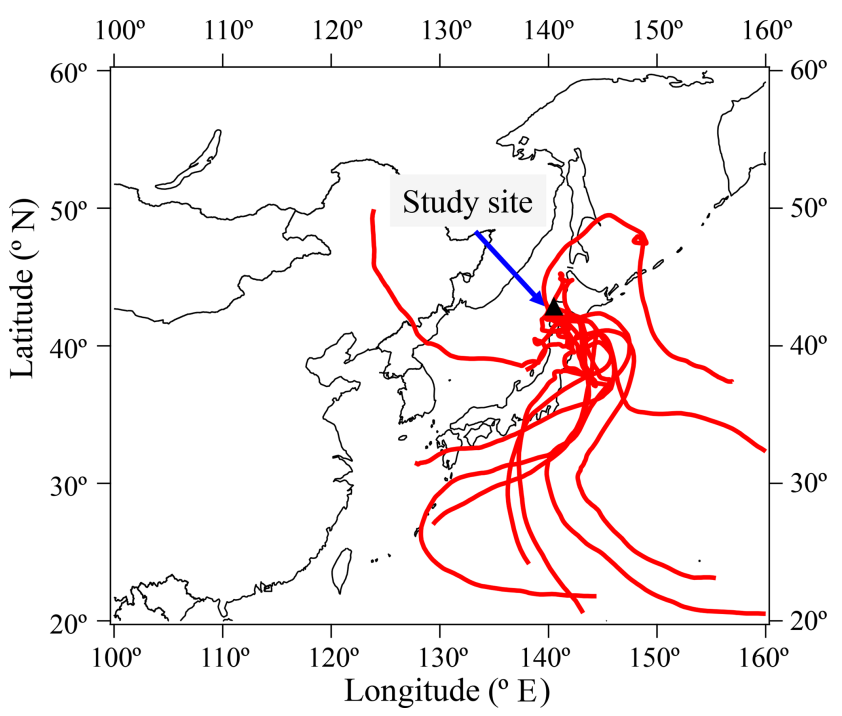

Figure 5. The 7-day air mass back trajectories at a height of $300 \mathrm{~m}$ a.s.l. during the sampling period. in Nagoya next to the Chubu University campus in October 2018 (average: $19 \pm 2.9^{\circ} \mathrm{C}$; Japan Meteorological Agency: https://www.jma.go.jp/jma/indexe.html, last access: 31 January 2019) was similar to that of Sapporo $\left(21 \pm 2.3^{\circ} \mathrm{C}\right)$ during the air-sampling period. These similarities provide a strong justification to utilize the soil sample from the Chubu University site as a surrogate of Sapporo forest soil. The soil sample was analyzed for LMW monoacids after water extraction employing the analytical protocol described in the experimental section. LMW normal $\left(\mathrm{C}_{1}-\mathrm{C}_{10}\right)$, branched $\left(\mathrm{iC}_{4}\right)$ and hydroxyl monoacids were detected in the soil sample (Kunwar et al., unpublished data, 2018). We found high abundances of formic $\left(7400 \mathrm{ng} \mathrm{g}_{\text {wet soil }}^{-1}\right)$ and acetic (4260 $\left.\mathrm{ng} \mathrm{g}_{\text {wet soil }}^{-1}\right)$ acids, which are significantly higher than the rest of the monoacids $\left(\sim 1800 \mathrm{ng} \mathrm{g}_{\text {wet soil }}^{-1}\right)$. Interestingly, hydroxy acids such as glycolic $\left(1680 \mathrm{ng} \mathrm{g}_{\text {wet soil }}^{-1}\right)$ and lactic (1860 $\mathrm{ng} \mathrm{g}_{\text {wet soil }}^{-1}$ ) acids were abundantly detected in the soil sample together with isobutyric acid ( $77 \mathrm{ng} \mathrm{g}_{\text {wet soil }}^{-1}$ ) (Kunwar et al., unpublished data, 2018). These preliminary results suggest that monoacids in the forest atmosphere are 

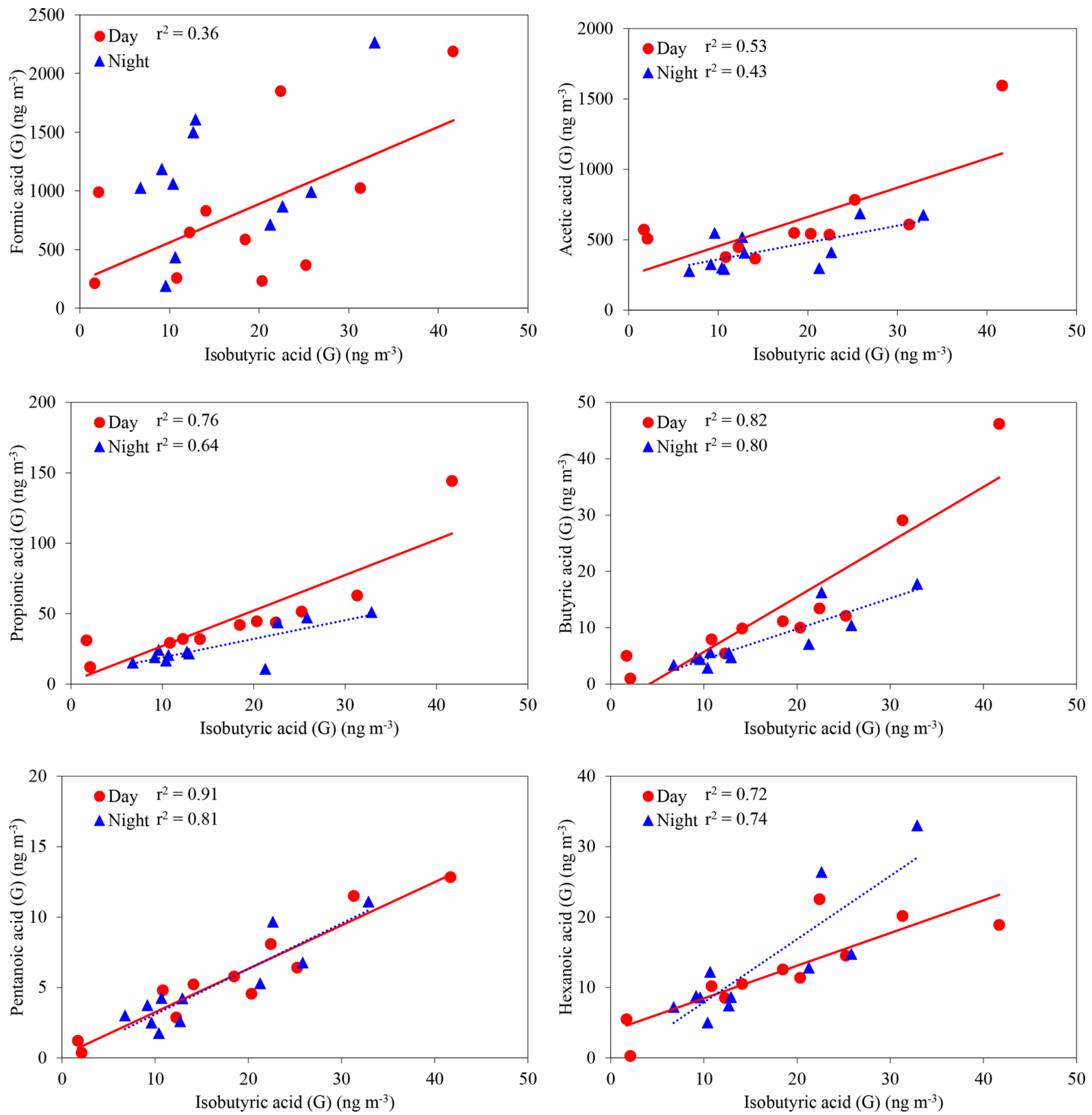

Figure 6. Concentrations of $\mathrm{C}_{1}-\mathrm{C}_{6}$ monoacids against isobutyric acid $\left(\mathrm{iC}_{4}\right)$ in the gas phase. The coefficient of determination shows that the regression line is statistically significant $(p<0.05)$.

in part derived from forest soil via microbial decomposition of plant debris and subsequent emission to the air.

However, it is not easy to estimate the quantitative contribution of monoacids from the forest floor. It is likely that molecular composition of LMW monoacids in soil may depend on a variety of parameters including types of microorganisms in soil, soil organic matter and exudation from plant roots. Conversely, we consider photooxidation of biogenic VOCs such as isoprene and monoterpenes to be an important source of formic and acetic acids in the atmosphere (Paulot et al., 2011).
In the particle phase, a positive correlation was observed between acetic acid and nonanoic acid (day: $r^{2}=0.63$, night: $r^{2}=0.63$ ) (Fig. 7). Unsaturated fatty acids (UFAs) such as oleic $\left(\mathrm{FA}_{18: 1}\right)$ and linoleic $\left(\mathrm{FA}_{18: 2}\right)$ acids are generally present in terrestrially higher plants and soil fungi (Yokouchi and Ambe, 1986; Kaur et al., 2005). Nonanoic ( $\left.\mathrm{C}_{9}\right)$ and hexanoic $\left(\mathrm{C}_{6}\right)$ acids are produced by the heterogenous oxidation of $\mathrm{FA}_{18: 1}$ and $\mathrm{FA}_{18: 2}$ in aerosols, respectively, via the cleavage of a double bond at the $\mathrm{C}_{9}$ position of UFAs (Yokouchi and Ambe, 1986; Kawamura and Gagosian, 1987). Longerchain monoacids may produce acetic acid via photochemi- 


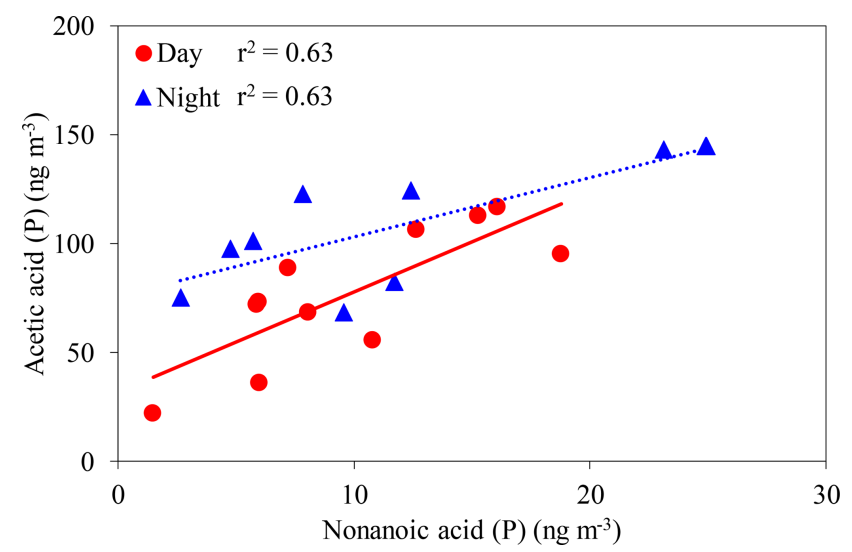

Figure 7. Concentrations of acetic acid in the particle phase as a function of those of nonanoic acid. The coefficient of determination shows that the regression line is statistically significant $(p<0.05)$.

cal breakdown with $\mathrm{OH}$ radicals. UFAs may also contribute to the formation of acetic acid in aerosol in a deciduous broadleaf forest.

Relatively high abundances of particulate lactic and isopentanoic acids were observed in the forest atmosphere (Table 1). A positive correlation was observed between lactic acid and isopentanoic acid in the particle phase $\left(r^{2}=\right.$ 0.98). Particulate lactic acid did not show correlations with other LMW monoacids detected in the particle phase $\left(r^{2}<0.17\right)$. Isopentanoic acid can be produced by bacteria Clostridium spp. and Bacteroides spp. (Effmert et al., 2012, and references therein). We confirmed that lactic acid is abundantly present in the forest soil from central Japan $\left(1860 \mathrm{ng} \mathrm{g}_{\text {wet soil }}^{-1}\right)$, but isopentanoic acid is below the detection limit (Kunwar et al., unpublished data, 2018). Lactic acid is produced not only by bacteria (lactobacillus) (Cabredo et al., 2009) but also by the oxidation of isoprene with ozone (Nguyen et al., 2010). The microflora community in soil system may be different between the two sites: a soil-sampling site in central Japan and an air-sampling site in northern Japan. More in-depth studies are needed to better understand the soil-to-air emissions of normal, branched and hydroxyl monoacids from the forest floor and the subsequent interaction between soil and the overlying atmosphere.

\subsection{Gas-particle partitioning of LMW monoacids}

Generally, $F_{\mathrm{p}}$ increases with an increase in carbon numbers of monoacids (Yatavelli et al., 2014) due to lower vapor pressures of higher MW organic acids. The smaller $F_{\mathrm{p}}$ values of formic (daytime: 0.08) and acetic (daytime: 0.14) acids can be explained by higher vapor pressure $\left(\mathrm{C}_{1}: 5.6 \times 10^{-2} \mathrm{~atm}\right.$; $\left.\mathrm{C}_{2}: 2.1 \times 10^{-2} \mathrm{~atm}\right)$ among LMW monoacids determined. The $F_{\mathrm{p}}$ values of formic and acetic acids measured in a deciduous broadleaf forest in the daytime are comparable to those reported from the Pacific Ocean $\left(\mathrm{C}_{1}: F_{\mathrm{p}}=0.04 ; \mathrm{C}_{2}\right.$ : $F_{\mathrm{p}}=0.06$; Miyazaki et al., 2014) and urban Los Angeles
$\left(\mathrm{C}_{1}: F_{\mathrm{p}}=0.16 ; \mathrm{C}_{2}: F_{\mathrm{p}}=0.06 ;\right.$ Kawamura et al., 2000$)$, in which the same sampling and analytical protocols were used.

Formic and acetic acids in the particle phase show clear day-night variations with higher concentrations in the nighttime than in the daytime. The higher concentrations in the nighttime may be associated with a shallower planetary boundary layer, which can accumulate organic acids near the ground surface. It is important to note that wind speed in the nighttime (average: $0.3 \mathrm{~m} \mathrm{~s}^{-1}$ ) was comparable to that in the daytime (average: $0.4 \mathrm{~m} \mathrm{~s}^{-1}$ ) and no correlation was observed between the concentrations of formic and acetic acids and wind speed $\left(r^{2}<0.01\right)$, suggesting an importance of other meteorological parameters that control the gas-particle portioning of organic acids.

We investigated the effects of ambient temperature on gasparticle partitioning of LMW monoacids. $F_{\mathrm{p}}$ values of formic and acetic acids were found to decrease with an increasing ambient temperature $\left(\mathrm{C}_{1}: r^{2}=0.49 ; \mathrm{C}_{2}: r^{2}=0.60\right)($ Fig. 8), whereas other LMW monoacids did not show clear correlations with ambient temperature $\left(r^{2}<0.37\right)$, except for butyric acid $\left(r^{2}=0.70\right)$ in the daytime. Although $F_{\mathrm{p}}$ values of LMW monoacids did not show a significant correlation with ambient temperature in the nighttime $\left(r^{2}<0.16\right)$, except for propionic acid $\left(r^{2}=0.31\right)$, we found that average $F_{\mathrm{p}}$ values of LMW monoacids in the nighttime were higher than those in the daytime (Table 1). A higher temperature promotes the transfer of aerosol-phase formic and acetic acids to the gas phase in the daytime by evaporation, which is consistent with Henry's law constants. Khan et al. (1995) reported that ambient temperature is an important factor to control the gasparticle partitioning of organic acids.

Conversely, we found that $F_{\mathrm{p}}$ values of formic and acetic acids increase with an increasing $\mathrm{RH}$ in the daytime $\left(\mathrm{C}_{1}\right.$ : $r^{2}=0.30 ; \mathrm{C}_{2}: r^{2}=0.55$ ) (Fig. 9), whereas other LMW monoacids did not show a significant correlation with $\mathrm{RH}$ $\left(r^{2}<0.20\right)$, except for butyric acid $\left(r^{2}=0.55\right)$. In the nighttime, $F_{\mathrm{p}}$ values of LMW monoacids did not show any significant correlation with RH $\left(r^{2}<0.15\right)$. Al-Hosney et al. (2005) and Prince et al. (2008) reported that the uptake of formic and acetic acids by $\mathrm{CaCO}_{3}$ can be enhanced by a higher $\mathrm{RH}\left(\mathrm{C}_{1}: \mathrm{RH}>62 \% ; \mathrm{C}_{2}: \mathrm{RH}>53 \%\right)$. In this study, we estimated liquid water contents (LWCs) of aerosols using the ISORROPIA II model (Fountoukis and Nenes, 2007), the data of inorganic ions and meteorological parameters. The estimated aerosol LWCs ranged from 1.4 to $14.6 \mu \mathrm{g} \mathrm{m}^{-3}$ (av. $6.4 \mu \mathrm{g} \mathrm{m}^{-3}$ ). Although $F_{\mathrm{p}}$ values of LMW monoacids did not show any strong correlations with LWC $\left(r^{2}<0.24\right)$, strong positive correlations were found between $\mathrm{RH}$ and aerosol LWC in the daytime $\left(r^{2}=0.47\right)$ and in the nighttime $\left(r^{2}=0.74\right)$. A higher RH may enhance the transfer of gaseous formic and acetic acids to the aerosol phase as a result of the condensation of water vapor on aerosol particles.

The larger $F_{\mathrm{p}}$ values were obtained for lactic acid (daytime: 0.60; nighttime: 0.69), although we obtained fewer smaller values for glycolic acid $(0.47-0.48$, Table 1$)$. These 

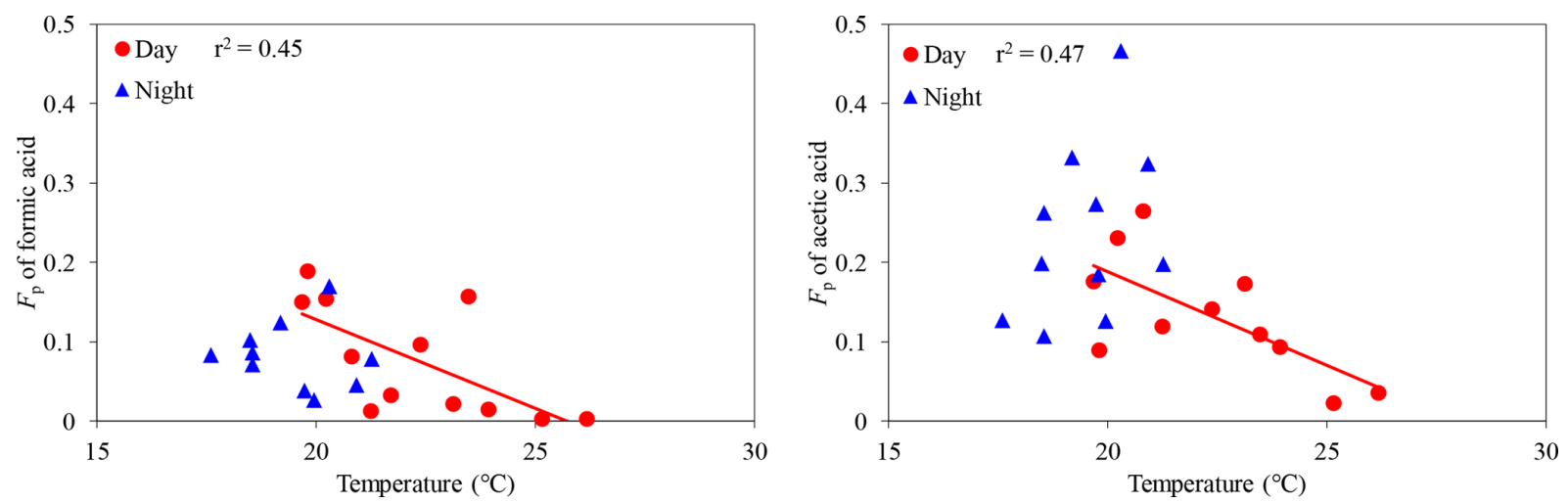

Figure 8. Particle-phase fractions $\left(F_{\mathrm{p}}\right)$ of formic and acetic acids against temperature. The coefficient of determination shows that the regression line is statistically significant $(p<0.05)$.
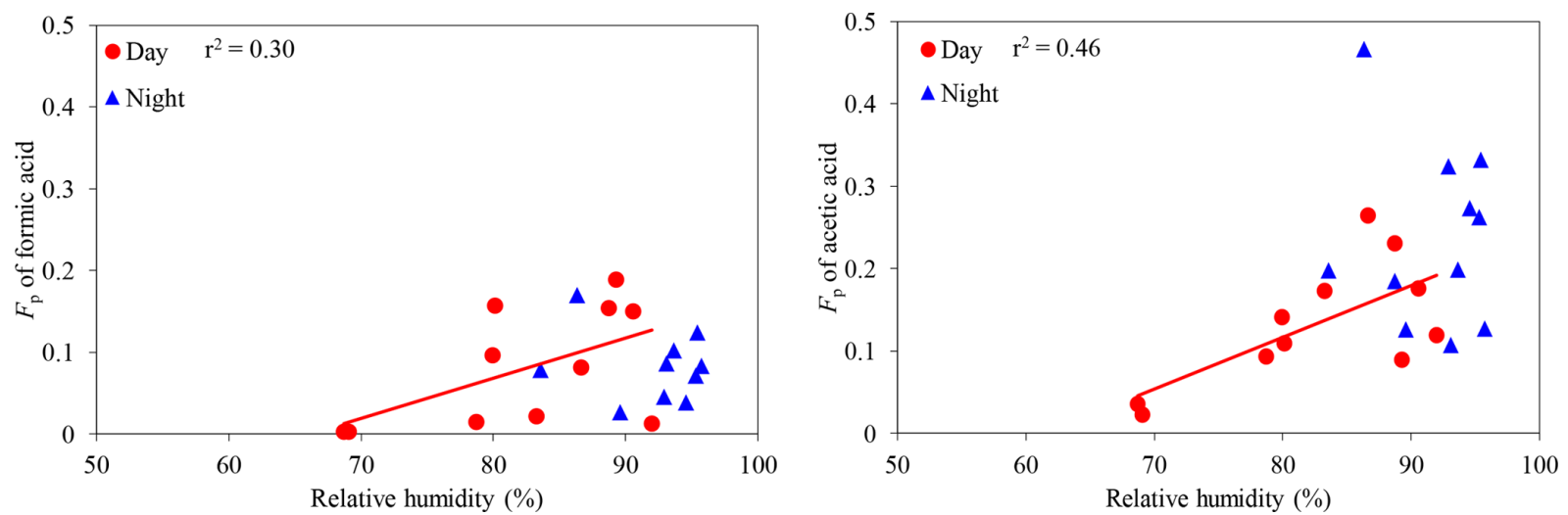

Figure 9. Particle-phase fractions $\left(F_{\mathrm{p}}\right)$ of formic and acetic acids against relative humidity. The coefficient of determination shows that the regression line is statistically significant $(p<0.1)$.

levels are comparable to those reported for the Pacific Ocean $\left(F_{\mathrm{p}}=0.82\right)$ (Miyazaki et al., 2014). Although the vapor pressure of lactic acid $\left(5.3 \times 10^{-4} \mathrm{~atm}\right)$ is higher than that of $\mathrm{C}_{5}-\mathrm{C}_{10}$ monoacids (vapor pressure: $1.6 \times 10^{-4}-1.6 \times$ $\left.10^{-10} \mathrm{~atm}\right)$, the $F_{\mathrm{p}}$ of lactic acid was larger than that of $\mathrm{C}_{5}-$ $\mathrm{C}_{10}$ monoacids $\left(F_{\mathrm{p}}: 0.11-0.50\right)$. This apparent discrepancy may suggest the possibility that lactic acid is partly present as bioaerosols such as bacterial particles possibly emitted from soil surface in the forest atmosphere.

Gaseous organic acids react with alkaline particles such as calcium carbonate, promoting the gas-particle partitioning of organic acids (Alexander et al., 2015). We calculated total cation equivalents $\left(\mathrm{Na}^{+}, \mathrm{NH}_{4}^{+}, \mathrm{K}^{+}, \mathrm{Mg}^{2+}\right.$ and $\mathrm{Ca}^{2+}$ ) minus total anion equivalents $\left(\mathrm{F}^{-}, \mathrm{MSA}^{-}, \mathrm{Cl}^{-}, \mathrm{NO}_{2}^{-}, \mathrm{NO}_{3}^{-}\right.$ and $\mathrm{SO}_{4}^{2-}$ ) including monoacids detected, although $\mathrm{CO}_{3}^{2-}$, $\mathrm{HCO}_{3}^{-}$and unidentified organic anions were not considered. Total cations were higher than total anions. No positive correlations were observed $\left(r^{2}<0.04\right)$ between $F_{\mathrm{p}}$ of individual LMW monoacids and excess cations. This result indicates that excess cations are not an important factor to control the gas-particle partitioning of LMW monoacids in the forest atmosphere. $F_{\mathrm{p}}$ values of LMW monoacids showed positive correlations with mass concentrations of total LMW monoacids in the particle phase $\left(r^{2}=0.24-0.46\right)$, except for $\mathrm{C}_{3}, \mathrm{C}_{9}$ and $\mathrm{C}_{10}$. This result suggests that gaseous LMW monoacids may be adsorbed on the preexisting particles in the forest atmosphere, although we did not measure the aerosol mass concentrations.

\section{Summary and conclusions}

We conducted simultaneous sampling of gaseous $(G)$ and particulate $(P)$ LMW monoacids in a deciduous broadleaf forest from northern Japan, followed by gas chromatographic determination after $p$-bromophenacyl ester derivatization of monoacids. LMW normal $\left(\mathrm{C}_{1}-\mathrm{C}_{10}\right)$, branched chain $\left(\mathrm{iC}_{4}-\right.$ $\mathrm{iC}_{6}$ ), hydroxyl (glycolic and lactic) and aromatic (benzoic) acids were detected in both gas and aerosol phases. Formic and acetic acids were found as the dominant species followed by propionic acid in the gas phase, whereas isopentanoic, acetic and formic acids were detected as major monoacids in the particle phase. Particle-phase fractions $\left(F_{\mathrm{p}}=P /(P+G)\right)$ 
of major LMW monoacids were low $\left(F_{\mathrm{p}}: 0.04-0.32\right)$, although nonanoic $\left(F_{\mathrm{p}}=0.50\right)$, decanoic $(0.43)$, isopentanoic $(0.68)$ and lactic (0.66) acids are largely present in the aerosol phase. Concentrations of $\mathrm{C}_{1}-\mathrm{C}_{6}$ monoacids in the gas phase showed positive correlations with isobutyric acid $\left(\mathrm{iC}_{4}\right)\left(r^{2}=\right.$ $0.21-0.91)$. Branched chain monoacids that are common metabolites of bacteria and fungi may be derived from the microbial degradation of leaf and plant debris in the forest soil. In addition to atmospheric oxidation of VOCs and UFAs as an important source of organic acids, we suggest that the forest floor is another source of gaseous LMW monoacids in the forest atmosphere. Acetic acid in the particle phase showed a positive correlation with nonanoic acid $\left(\mathrm{C}_{9}\right)$, which is produced by the oxidation of unsaturated fatty acids such as oleic acid. $F_{\mathrm{p}}$ of formic and acetic acids showed negative correlations with ambient temperature $\left(\mathrm{C}_{1}: r^{2}=0.49 ; \mathrm{C}_{2}\right.$ : $\left.r^{2}=0.60\right)$ and positive correlations with $\mathrm{RH}\left(\mathrm{C}_{1}: r^{2}=0.30\right.$; $\left.\mathrm{C}_{2}: r^{2}=0.55\right)$ in the daytime, suggesting that these meteorological parameters are important factors to control the gas-particle portioning of LMW monoacids in the forest atmosphere. The present study demonstrates that deciduous broadleaf forest is an important source of LMW monoacids in the gas and particle phases in the atmosphere of northern Japan.

Data availability. The Meteorological Data Explorer (METEX) provided by the National Institute for Environmental Studies (http: //db.cger.nies.go.jp/metex/index.html, last access: 12 August 2018) and the Japan Meteorological Agency (https://www.jma.go.jp/jma/ indexe.html, last access: 31 January 2019) are available. The data of this paper are available upon request to K. Kawamura (kkawamura@isc.chubu.ac.jp).

Author contributions. TM, KK and YM contributed equally to the experiment and preparation of the paper. BK carried out the soil analysis. SKRB performed the ISORROPIA II model calculations.

Competing interests. The authors declare that they have no conflict of interest.

Acknowledgements. This study was in part supported by JSPS KAKENHI grant numbers JP19204055 and JP18K18181. We thank Katsumi Yamanoi and Yasuko Mizoguchi of the Forestry and Forest Products Research Institute for the courtesy of using the sampling site.

Edited by: Yugo Kanaya

Reviewed by: two anonymous referees

\section{References}

Alexander, J. M., Grassian, V. H., Young, M. A., and Kleiber, P. D.: Optical properties of selected components of mineral dust aerosol processed with organic acids and humic material, J. Geophys. Res.-Atmos., 120, 2437-2452, https://doi.org/10.1002/2014JD022782, 2015.

Al-Hosney, H. A. Carlos-Cuellar, S., Baltrusaitis, J., and Grassian, V. H.: Heterogeneous uptake and reactivity of formic acid on calcium carbonate particles: a Kunden cell reactor, FTIR and SEM study, Phys. Chem. Chem. Phys., 7, 3587-3595, https://doi.org/10.1039/b510112c, 2005.

Andreae, M. O., Talbot, R. W., Andreae, T. W., and Harris, R. C.: Formic and acetic acid over the central Amazon region, Brazil. 1. Dry season, J. Geophys. Res., 93, 1616-1624, doi.org/10.1029/JD093iD02p01616, 1988.

Berg Jr., W. W. and Winchester, J. M.: Aerosol chemistry of the marine atmospherem in: Chemical Oceanography, edited by: J. P. Riley and R. Chester, 2nd Ed. 7, Academic Press, London, UK, 173-231, 1978.

Boreddy, S. K. R. and Kawamura, K.: A 12-year observation of water-soluble ions in TSP aerosols collected at a remote marine location in the western North Pacific: an outflow region of Asian dust, Atmos. Chem. Phys., 15, 6437-6453, https://doi.org/10.5194/acp-15-6437-2015, 2015.

Boreddy, S. K. R., Mochizuki, T., Kawamura, K., Bikkina, S., and Sarin, M. M.: Homologous series of low molecular weight $\left(\mathrm{C}_{1}-\mathrm{C}_{10}\right)$ monocarboxylic acids, benzoic acid and hydroxyacids in fine-mode $\left(\mathrm{PM}_{2.5}\right)$ aerosols over the Bay of Bengal: Influence of heterogeneity in air masses and formation pathways, Atmos. Environ., 167, 170-180, https://doi.org/10.1016/j.atmosenv.2017.08.008, 2017.

Cabredo, S., Parra, A., Saenz, C., and Anzano, J.: Bioaerosols chemometric characterization by laser-induced fluorescence: air sample analysis, Talanta, 77, 1837-1842, doi.10.1016/j.talanta.2008.10.030, 2009.

Curl, E. A.: The rhizosphere relation to pathogen behaviour and root disease, Plant Dis., 66, 624-630, 1982.

Duce, R. A., Arimoto, R., Ray, B. J., Unni, C. K., and Harder, P. J.: Atmospheric trace elements at Enewetak Atoll: 1, concentrations, sources, and temporal variability, J. Geophys. Res., 88, 5321-5342, https://doi.org/10.1029/JC088iC09p05321, 1983.

Effmert, U., Kalderás, J., Warnke, R., and Piechulla, B.: Volatile mediated interactions between bacteria and fungi in the soil, J. Chem. Ecol., 38, 665-703, https://doi.org/10.1007/s10886-0120135-5, 2012.

Fountoukis, C. and Nenes, A.: ISORROPIA II: a computationally efficient thermodynamic equilibrium model for $\mathrm{K}^{+}-$ $\mathrm{Ca}^{2+}-\mathrm{Mg}^{2+}-\mathrm{NH}_{4}^{+}-\mathrm{Na}^{+}-\mathrm{SO}_{4}^{2-}-\mathrm{NO}_{3}^{-}-\mathrm{Cl}^{-}-\mathrm{H}_{2} \mathrm{O}$ aerosols, Atmos. Chem. Phys., 7, 4639-4659, https://doi.org/10.5194/acp-74639-2007, 2007.

Jardine, K., Yañez Serrano, A., Arneth, A., Abrell, L., Jardine, A., Artaxo, P., Alves, E., Kesselmeier, J., Taylor, T., Saleska, S., and Huxman, T.: Ecosystem-scale compensation points of formic and acetic acid in the central Amazon, Biogeosciences, 8, 37093720, https://doi.org/10.5194/bg-8-3709-2011, 2011.

Kanakidou, M., Seinfeld, J. H., Pandis, S. N., Barnes, I., Dentener, F. J., Facchini, M. C., Van Dingenen, R., Ervens, B., Nenes, A., Nielsen, C. J., Swietlicki, E., Putaud, J. P., Balkanski, Y., Fuzzi, S., Horth, J., Moortgat, G. K., Winterhalter, R., Myhre, C. E. 
L., Tsigaridis, K., Vignati, E., Stephanou, E. G., and Wilson, J.: Organic aerosol and global climate modelling: a review, Atmos. Chem. Phys., 5, 1053-1123, https://doi.org/10.5194/acp-5-10532005, 2005.

Kaur, A., Chaudhary, A., Kaur, A., Choudhary, R., and Kaushik, R.: Phospholipid fatty acid - A bioindicator of environment monitoring and assessment in soil ecosystem, Current Sci., 89, 11031112, 2005.

Kawamura, K. and Gagosian, R. B.: Implication of $\omega$-oxocarboxylic acids in the remote marine atmosphere for photooxidation of unsaturated fatty acids, Nature, 325, 330-332, https://doi.org/10.1038/325330a0, 1987.

Kawamura, K. and Kaplan, I. R.: Capillary gas chromatography determination of volatile organic acids in rain and fog samples, Anal. Chem., 56, 1616-1620, https://doi.org/10.1021/ac00273a018, 1984.

Kawamura, K., Ng, L. L., and Kaplan, I. R.: Determination of organic-acids $\left(\mathrm{C}_{1}-\mathrm{C}_{10}\right)$ in the atmosphere, motor exhausts, and engine oils, Environ. Sci. Technol., 19, 1082-1086, https://doi.org/10.1021/es00141a010, 1985.

Kawamura, K., Steinberg, S., and Kaplan, I. R.: Concentrations of mono- and di-carboxylic acids and aldehydes in southern California wet precipitations: comparison of urban and nonurban samples and compositional changes during scavenging, Atmos. Environ., 30, 1035-1052, https://doi.org/10.1016/13522310(95)00404-1, 1996.

Kawamura, K., Steinberg, S., and Kaplan, I. R.: Homologous series of $\mathrm{C}_{1}-\mathrm{C}_{10}$ monocarboxylic acids and $\mathrm{C}_{1}-\mathrm{C}_{6}$ carbonyls in Los Angeles and motor vehicle exhausts, Atmos. Environ, 34, 41754191, https://doi.org/10.1016/S1352-2310(00)00212-0, 2000.

Kawamura, K., Matsumoto, K., Tachibana, E., and Aoki, $\mathrm{K}$.: Low molecular weight $\left(\mathrm{C}_{1}-\mathrm{C}_{10}\right)$ monocarboxylic acids, dissolved organic carbon and major inorganic ions in alpine snow pit sequence from a high mountain site, central Japan, Atmos. Environ., 62, 272-280, https://doi.org/10.1016/j.atmosenv.2012.08.018, 2012.

Keene, W. C., Galloway, J. N., and Holden Jr., J. D.: Measurement of weak organic acidity in precipitation from remote areas of the world, J. Geophys. Res., 88, 5122-5130, https://doi.org/10.1029/JC088iC09p05122, 1983.

Kesselmeier, J. and Staudt, M.: Biogenic volatile organic compounds (VOC): An overview on emission, physiology, and ecology, J. Atmos. Chem., 33, 23-88, https://doi.org/10.1023/A:1006127516791, 1999.

Kesselmeier, J., Bode, K., Hofmann, U., Muller, H., Schafer, L., Wolf, A., Ciccioli, P., Brancaleoni, E., Cecinato, A., Frattoni, M., Foster, P., Ferrari, C., Jacob, V., Fugit, J. L., Dutaur, L., Simon, V., and Torres, L.: Emission of short chained organic acids, aldehydes and monoterpenes from Quercus ilex L. and Pinus pinea $\mathrm{L}$. in relation to physiological activities, carbon budget and emission algorithms, Atmos. Environ., 31, 119-133, https://doi.org/10.1016/S1352-2310(97)00079-4, 1997.

Khan, J., Brimblecombe, P., and Glegg, S. L.: Solubilities of pyruvic acid and the lower $\left(\mathrm{C}_{1}-\mathrm{C}_{6}\right)$ carboxylic acids. Experimental determination of equilibrium vapour pressures above pure aqueous and salt solutions, J. Atmos. Chem., 22, 285-302, https://doi.org/10.1007/BF00696639, 1995.
Legrand, M., Preunkert, S., and Jourdain, B.: Year-round records of gas and particulate formic and acetic acids in the boundary layer at Dumont d'Urville, coastal Antarctica, J. Geophys. Res., 109, D06313, https://doi.org/10.1029/2003JD003786, 2004.

Liu, J., Zhang, Z., Parker, E. T., Veres, P. R., Toberts, J. M., de Gouw, J. A., Hayes, P. L., Jimenez, J. L., Murphy, J. G., Ellis, R. A., Huey, L. G., and Weber R. J.: On the gas-particle partitioning of soluble organic aerosol in two urban atmospheres with contrasting emissions: 2. Gas and particle phase formic acid, J. Geophys. Res., 117, D00V21, https://doi.org/10.1029/2012JD017912, 2012.

Miyazaki, Y., Jung, Y., Fu, P., Mizoguchi, Y., Yamanoi, K., and Kawamura, K.: Evidence of formation of submicrometer water-soluble organic aerosols at a deciduous forest site in northern Japan in summer, J. Geophys. Res., 117, D19213, https://doi.org/10.1029/2012JD018250, 2012a.

Miyazaki, Y., Fu, P. Q., Kawamura, K., Mizoguchi, Y., and Yamanoi, K.: Seasonal variations of stable carbon isotopic composition and biogenic tracer compounds of water-soluble organic aerosols in a deciduous forest, Atmos. Chem. Phys., 12, 13671376, https://doi.org/10.5194/acp-12-1367-2012, 2012b.

Miyazaki, Y., Sawano, M., and Kawamura, K.: Low-molecularweight hydroxyacids in marine atmospheric aerosol: evidence of a marine microbial origin, Biogeosciences, 11, 4407-4414, https://doi.org/10.5194/bg-11-4407-2014, 2014.

Mochizuki, T., Kawamura, K., Aoki, K., and Sugimoto, N.: Long-range atmospheric transport of volatile monocarboxylic acids with Asian dust over a high mountain snow site, central Japan, Atmos. Chem. Phys., 16, 14621-14633, https://doi.org/10.5194/acp-16-14621-2016, 2016.

Mochizuki, T., Kawamura, K., Nakamura, S., Kanaya, Y., and Wang, Z.: Enhanced levels of atmospheric lowmolecular weight monocarboxylic acids in gas and particulates over Mt. Tai, North China, during field burning of agricultural wastes, Atmos. Environ., 171, 237-247, https://doi.org/10.1016/j.atmosenv.2017.10.026, 2017.

Nguyen, T. B., Bateman, A. P., Bones, D. L., Nizkorodov, S. A., Laskin, J., and Laskin, A.: High-resolution mass spectrometry analysis of secondary organic aerosol generated by ozonolysis of isoprene, Atmos. Environ., 44, 1032-1042, https://doi.org/10.1016/j.atmosenv.2009.12.019, 2010.

Paulot, F., Wunch, D., Crounse, J. D., Toon, G. C., Millet, D. B., DeCarlo, P. F., Vigouroux, C., Deutscher, N. M., González Abad, G., Notholt, J., Warneke, T., Hannigan, J. W., Warneke, C., de Gouw, J. A., Dunlea, E. J., De Mazière, M., Griffith, D. W. T., Bernath, P., Jimenez, J. L., and Wennberg, P. O.: Importance of secondary sources in the atmospheric budgets of formic and acetic acids, Atmos. Chem. Phys., 11, 1989-2013, https://doi.org/10.5194/acp-11-1989-2011, 2011.

Prince, A. P., Kleiber, P. D., Grassian, V. H., and Young, M. A.: Reactive uptake of acetic acid on calcite and nitric acid reacted calcite aerosol in an environmental reaction chamber, Phys. Chem. Chem. Phys., 10, 142-152, https://doi.org/10.1039/B712915G, 2008.

Shen, Y., Ström, L., Jonssön, J. Å., and Tyler, G.: Low-molecular organic acids in the rhizosphere soil solution of beech forest (Fagus sylvatica L.) cambisols determined by ion chromatography using supported liquid membrane enrichment technique, Soil 
Biol. Biochem., 28, 1163-1169, https://doi.org/10.1016/00380717(96)00119-8, 1996.

Stavrakou, T., Muller, J.-F., Peeters, J., Razavi, A., Clarisse, L., Clerbaux, C., Coheur, P.-F., Hurtmans, D., De Maziere, M., Vigouroux, C., Deutscher, N. M., Griffith, D. W. T., Jones, N., and Paton-Walsh, C.: Satellite evidence for a large source of formic acid from boreal and tropical forests, Nat. Geosci., 5, 2630, https://doi.org/10.1038/ngeo1354, 2012.

Tsai, Y. I. and Kuo, S. C.: Contributions of low molecular weight carboxylic acids to aerosols and wet deposition in a natural subtropical broad-leaved forest environment, Atmos. Environ., 81, 270-279, https://doi.org/10.1016/j.atmosenv.2013.08.061, 2013.

Yamanoi, K., Mizoguchi, Y., and Utsugi, H.: Effects of a windthrow disturbance on the carbon balance of a broadleaf deciduous forest in Hokkaido, Japan, Biogeosciences, 12, 6837-6851, https://doi.org/10.5194/bg-12-6837-2015, 2015.
Yatavelli, R. L. N., Stark, H., Thompson, S. L., Kimmel, J. R., Cubison, M. J., Day, D. A., Campuzano-Jost, P., Palm, B. B., Hodzic, A., Thornton, J. A., Jayne, J. T., Worsnop, D. R., and Jimenez, J. L.: Semicontinuous measurements of gas-particle partitioning of organic acids in a ponderosa pine forest using a MOVI-HRToF-CIMS, Atmos. Chem. Phys., 14, 1527-1546, https://doi.org/10.5194/acp-14-1527-2014, 2014.

Yokouchi, Y. and Ambe, Y.: Characterization of polar organics in airborne particulate matter, Atmos. Environ., 81, 270-279, https://doi.org/10.1016/0004-6981(86)90121-6, 1986. 